\title{
Impact of different anti-HCV regimens on platelet count during treatment in Egyptian patients
}

Sara Abd El Ghany ${ }^{1}$, Noha M. El Husseiny ${ }^{1,2^{*}}$ (D) Mohamed Roshdy ${ }^{1}$, Heba Moustafa ${ }^{1}$, Mohamed Taha Atallah ${ }^{3}$, Ahmed Fathy ${ }^{1,2}$, Heba H. El Demellawy ${ }^{4}$, Asmaa M. Abdelhameed ${ }^{1,2}$ and Doaa M. El Demerdash ${ }^{1}$

\begin{abstract}
Background: Side effects of antiviral therapies for hepatitis C, especially hematologic abnormalities, may decrease both therapeutic adherence and therapeutic success rate. Adherence to therapy is essential to achieve an early viral response (EVR), and this is vital for attaining a sustained viral response (SVR). Discontinuation of anti-viral therapy is the only way to prevent progressive thrombocytopenia; however, discontinuation of therapy may reduce the rate of viral clearance and SVR. Our aim is to study effects of antiviral therapy for HCV on platelet count. One hundred sixty eight adult patients with chronic hepatitis $C$ were enrolled in this study and subcategorized into 3 groups: group (1) contains 56 patients receiving IFN, ribavirin and sofosbuvir (triple therapy); group (2) contains 55 patients receiving ribavirin and sofosbuvir (SOF/RBV); and group (3) contains 57 patients receiving simeprevir and sofosbuvir (SIM/SOF). HCV RNA by PCR were checked basically for all studied patients. Follow-up platelet count was done weekly during the first month then monthly till end of treatment. Follow-up of platelet count decrement was assessed at the 2nd week, 4th week and end of antiviral therapy for all studied groups.

Results: We found that in the 2nd week and 4th week, most of patients (76.2\%, 71.4\%) showed platelet count decrement during antiviral therapy. The decrement of platelet at the 2nd week, 4th week and at end of treatment was much noticed with the SOF/RBV antiviral therapy studied group. None of the patients developed severe thrombocytopenia; none of the patients needed to stop antiviral therapy due to thrombocytopenia, only 6 patients needed dose modification, most of them were from the triple therapy group.

Conclusion: We concluded that thrombocytopenia in chronic HCV infection has a multifactorial pathophysiology and remains a major problem. The recent change in direct-acting antiviral therapy (DAA) without IFN, as the frontline therapy for $\mathrm{HCV}$, permit to avoid the dilemmas associated with initiating or maintaining IFN-based antiviral therapy. DAAs, with high SVR and few haematological adverse effects, have been shown to improve thrombocytopenia associated with HCV infection as well as advanced hepatic disease.
\end{abstract}

Keywords: HCV, Direct antiviral therapy, Thrombocytopenia

\footnotetext{
* Correspondence: Noha_el_husseiny77@yahoo.com

'Internal Medicine Department, Faculty of Medicine, Cairo University, Cairo,

Egypt

${ }^{2}$ Armed Forces Faculty of Medicine (AFCM), Cairo, Egypt

Full list of author information is available at the end of the article
}

Springer Open

(c) The Author(s). 2020 Open Access This article is licensed under a Creative Commons Attribution 4.0 International License, which permits use, sharing, adaptation, distribution and reproduction in any medium or format, as long as you give appropriate credit to the original author(s) and the source, provide a link to the Creative Commons licence, and indicate if changes were made. The images or other third party material in this article are included in the article's Creative Commons licence, unless indicated otherwise in a credit line to the material. If material is not included in the article's Creative Commons licence and your intended use is not permitted by statutory regulation or exceeds the permitted use, you will need to obtain permission directly from the copyright holder. To view a copy of this licence, visit http://creativecommons.org/licenses/by/4.0/. 


\section{Background}

Egypt has the highest $\mathrm{HCV}$ prevalence in the world at approximately $15 \%$, and more than $90 \%$ of cases are genotype 4 [1].

Patients with chronic hepatitis treated with antiviral therapy experience a response superior to that of therapies used in the past. However, side effects, especially haematologic abnormalities, may decrease both therapeutic adherence and therapeutic success rate. Thrombocytopenia is one of the potential hematologic abnormalities associated with peg-IFN-a-based therapy [2].

Adherence to therapy is essential to achieve an early viral response (EVR), and this is vital for attaining a sustained viral response (SVR) [3].

Discontinuation of antiviral therapy is the only way to prevent progressive thrombocytopenia; however, discontinuation of therapy may reduce the rate of viral clearance and sustained virological response (SVR) [4].

Studies to identify risk factors for antiviral therapyinduced severe thrombocytopenia are essential but are rarely conducted especially in the Egyptian population of the largest HCV epidemic in the world.

No previous studies were done on Egyptian patients to the compare effect of different antiviral therapy combinations on platelet count. Through this retrospective study, we tried to identify predictors of thrombocytopenia in HCV-treated patients on different regimens.

\section{Methods}

This research was approved by the Research Ethical Committee of Faculty of Medicine-Cairo University. It is a retrospective study. It included 168 chronic hepatitis $\mathrm{C}$ Egyptian patients receiving antiviral therapy. All methods were performed in accordance with the relevant guidelines and regulations. Informed consents were obtained. All were treated between 2015 and 2017 in Cairo Fatemic Hospital and Internal Medicine department of Kasr Al Aini- Faculty of Medicine. We revised all patients' files. Inclusion criteria included age $>18$ years, having chronic hepatitis $\mathrm{C}$ and receiving antiviral therapy. Exclusion criteria included co-infection with HBV or HIV and hepatitis other than hepatitis C (eg. autoimmune) and baseline severe thrombocytopenia below 50,000/ $\mathrm{\mu l}$. Dose modification of a treatment line was done if platelet count dropped below 30,000/ $\mu$ and discontinuation in case of persistent drop even with dose reduction.

Patients were subcategorized into 3 groups: group (1) consists of 56 patients who received IFN, ribavirin and sofosbuvir (triple therapy); group (2) consists of 55 patients who received ribavirin and sofosbuvir (SOF/RBV); and group (3) consists of 57 patients who received simeprevir and sofosbuvir (SIM/SOF). For all, the files were revised for full history and clinical examination, $\mathrm{CBC}$,
HCV RNA by PCR. Fibroscan was done for 61 patients, and liver biopsy was done for 22 patients. Follow-up platelet count weekly during the 1st month of therapy, rate of platelet decline (\%) especially at the 2nd week of therapy, then monthly till end of therapy.

Follow-up HCV RNA by PCR was done at week 4 and at the end of therapy. FIB-4 score was calculated for all patients [5]. Child score was calculated for all patients [6].

\section{Statistical methods}

Data were coded and entered using the statistical package SPSS (Statistical Package for the Social Sciences) version 24. Data was summarized using mean, standard deviation, median, minimum and maximum in quantitative data and using frequency (count) and relative frequency (percentage) for categorical data. Comparisons between quantitative variables were done using the nonparametric Kruskal-Wallis and Mann-Whitney tests. For comparing categorical data, Chi square $\left(\chi^{2}\right)$ test was performed. Exact test was used instead when the expected frequency is less than 5. Correlations between quantitative variables were done using Spearman correlation coefficient. $P$ values less than 0.05 were considered as statistically significant.

\section{Results}

Tables 1 and 2 demonstrate comparison of nonparametric and parametric data respectively of the three studied groups. Group 2 (SOF/RBV) showed significantly higher percentage of patients with splenomegaly and liver cirrhosis and those who received previous treatment.

Baseline haematological parameters where significantly more favourable in group 1 (triple therapy line). The baseline mean platelet count in group 2 (SOF/RBV) was lower as compared with the other 2 groups; also, the HCV load was significantly higher in this group.

Table 3 demonstrates the percentage of patients showing platelet decrement as assessed at the 2nd week, 4th week and end of antiviral therapy. Overall, most patients, $76.2 \%$ in the 2 nd week and $71.4 \%$ in the 4 th week, exhibited decrease in platelet count. These percentages dropped to $54.8 \%$ at the end of treatment. Highest proportion of patients with decrease in platelet count was found in group 1 (INF/SOF/RBV) 89.3\%, 82.1\% and $73.2 \%$ at 2 nd week, 4th week and end of antiviral therapy.

Regarding the magnitude of drop of platelet count reported as mean and percent of baseline count, as presented in Table 4, group 1 showed the highest percent of drop from the baseline: $28 \%, 26 \%$ and $25 \%$ in the 2 nd week, 4th week and end of antiviral therapy, while group 2 showed lowest level (mean count) and earliest recovery 
Table 1 Non parametric parameters of the three groups on anti-HCV treatment

\begin{tabular}{|c|c|c|c|c|c|c|c|}
\hline & \multicolumn{2}{|c|}{ SIM/SOF } & \multicolumn{2}{|c|}{ SOF/RBV } & \multicolumn{2}{|l|}{ Triple } & \multirow[t]{2}{*}{$p$ value } \\
\hline & Count & $\%$ & Count & $\%$ & Count & $\%$ & \\
\hline \multicolumn{8}{|l|}{ Sex } \\
\hline Male & 26 & $45.6 \%$ & 32 & $58.2 \%$ & 38 & $67.9 \%$ & \multirow[t]{2}{*}{0.057} \\
\hline Female & 31 & $54.4 \%$ & 23 & $41.8 \%$ & 18 & $32.1 \%$ & \\
\hline \multicolumn{8}{|l|}{ Residency } \\
\hline Urban & 34 & $59.6 \%$ & 42 & $76.4 \%$ & 35 & $62.5 \%$ & \multirow[t]{2}{*}{0.138} \\
\hline Rural & 23 & $40.4 \%$ & 13 & $23.6 \%$ & 21 & $37.5 \%$ & \\
\hline \multicolumn{8}{|l|}{ History of previous ttt } \\
\hline ttt naïve & 54 & $94.7 \%$ & 35 & $64.8 \%$ & 42 & $75.0 \%$ & \multirow[t]{2}{*}{$<0.001$} \\
\hline ttt experienced & 3 & $5.3 \%$ & 19 & $35.2 \%$ & 14 & $25.0 \%$ & \\
\hline \multicolumn{8}{|l|}{ Smoking } \\
\hline Yes & 6 & $10.5 \%$ & 7 & $12.7 \%$ & 11 & $19.6 \%$ & \multirow[t]{2}{*}{0.354} \\
\hline No & 51 & $89.5 \%$ & 48 & $87.3 \%$ & 45 & $80.4 \%$ & \\
\hline \multicolumn{8}{|c|}{ Comorbidities (diabetes and/or hypertension) } \\
\hline Yes & 21 & $36.8 \%$ & 21 & $38.2 \%$ & 18 & $32.1 \%$ & \multirow[t]{2}{*}{0.783} \\
\hline No & 36 & $63.2 \%$ & 34 & $61.8 \%$ & 38 & $67.9 \%$ & \\
\hline \multicolumn{8}{|l|}{ Liver by ultrasound } \\
\hline Normal & 0 & $0.0 \%$ & 2 & $3.6 \%$ & 8 & $14.3 \%$ & \multirow[t]{3}{*}{$<0.001$} \\
\hline Cirrhotic & 31 & $54.4 \%$ & 47 & $85.5 \%$ & 25 & $44.6 \%$ & \\
\hline Abnormal echopattern & 26 & $45.6 \%$ & 6 & $10.9 \%$ & 23 & $41.1 \%$ & \\
\hline \multicolumn{8}{|l|}{ Spleen by ultrasound } \\
\hline Enlarged & 28 & $49.1 \%$ & 41 & $74.5 \%$ & 35 & $62.5 \%$ & \multirow[t]{2}{*}{0.021} \\
\hline Average & 29 & $50.9 \%$ & 14 & $25.5 \%$ & 21 & $37.5 \%$ & \\
\hline \multicolumn{8}{|l|}{ Ascites by ultrasound } \\
\hline Yes & 0 & $0.0 \%$ & 1 & $1.8 \%$ & 1 & $1.8 \%$ & \multirow[t]{2}{*}{0.549} \\
\hline No & 57 & $100.0 \%$ & 54 & $98.2 \%$ & 55 & $98.2 \%$ & \\
\hline \multicolumn{8}{|l|}{ Child score calculation } \\
\hline A5 & 25 & $43.9 \%$ & 26 & $47.3 \%$ & 50 & $89.3 \%$ & \multirow[t]{4}{*}{$<0.001$} \\
\hline A6 & 32 & $56.1 \%$ & 21 & $38.2 \%$ & 4 & $7.1 \%$ & \\
\hline B7 & 0 & $0.0 \%$ & 7 & $12.7 \%$ & 2 & $3.6 \%$ & \\
\hline B8 & 0 & $0.0 \%$ & 1 & $1.8 \%$ & 0 & $0.0 \%$ & \\
\hline \multicolumn{8}{|l|}{ Stage of fibrosis } \\
\hline F1 & 3 & $27.3 \%$ & 1 & $4.0 \%$ & 2 & $8.0 \%$ & 0.003 \\
\hline $\mathrm{F} 2$ & 1 & $9.1 \%$ & 1 & $4.0 \%$ & 0 & $0.0 \%$ & \\
\hline F3 & 1 & $9.1 \%$ & 4 & $16.0 \%$ & 14 & $56.0 \%$ & \\
\hline F4 & 6 & $54.5 \%$ & 18 & $72.0 \%$ & 9 & $36.0 \%$ & \\
\hline F5 & 0 & $0.0 \%$ & 1 & $4.0 \%$ & 0 & $0.0 \%$ & \\
\hline Stage of necroinflammato & & & & & & & \\
\hline A1 & 1 & $50.0 \%$ & 2 & $25.0 \%$ & 4 & $33.3 \%$ & 0.749 \\
\hline$A 2$ & 1 & $50.0 \%$ & 4 & $50.0 \%$ & 7 & $58.3 \%$ & \\
\hline A3 & 0 & $0.0 \%$ & 1 & $12.5 \%$ & 0 & $0.0 \%$ & \\
\hline A7 & 0 & $0.0 \%$ & 0 & $0.0 \%$ & 1 & $8.3 \%$ & \\
\hline $\mathrm{A} 10$ & 0 & $0.0 \%$ & 1 & $12.5 \%$ & 0 & $0.0 \%$ & \\
\hline
\end{tabular}

Week 4 HCV RNA by PCR 
Table 1 Non parametric parameters of the three groups on anti-HCV treatment (Continued)

\begin{tabular}{|c|c|c|c|c|c|c|c|}
\hline & \multicolumn{2}{|c|}{$\mathrm{SIM} / \mathrm{SOF}$} & \multicolumn{2}{|c|}{ SOF/RBV } & \multicolumn{2}{|l|}{ Triple } & \multirow[t]{2}{*}{$p$ value } \\
\hline & Count & $\%$ & Count & $\%$ & Count & $\%$ & \\
\hline Positive & 3 & $5.3 \%$ & 7 & $12.7 \%$ & 2 & $3.6 \%$ & 0.183 \\
\hline Negative & 54 & $94.7 \%$ & 48 & $87.3 \%$ & 54 & $96.4 \%$ & \\
\hline \multicolumn{8}{|c|}{ Week 12 HCV RNA by PCR } \\
\hline Positive & 2 & $3.6 \%$ & 1 & $1.8 \%$ & 0 & $0.0 \%$ & 0.325 \\
\hline Negative & 53 & $96.4 \%$ & 54 & $98.2 \%$ & 56 & $100.0 \%$ & \\
\hline \multicolumn{8}{|c|}{ HCV antiviral dose modification } \\
\hline No & 57 & $100.0 \%$ & 54 & $98.2 \%$ & 51 & $91.1 \%$ & 0.025 \\
\hline Modified & 0 & $0.0 \%$ & 1 & $1.8 \%$ & 5 & $8.9 \%$ & \\
\hline
\end{tabular}

(in the 4th week) of platelet count, considering that this group had lowest pre-treatment count.

The drop in the mean platelet count was modest as illustrated in Table 4 and Fig. 1; in all groups, according to the mean platelet count in the 2nd and 4th weeks and end of treatment, the reported thrombocytopenia is grade 1 $\left(75,000\right.$ to $\left.150,000 / \mathrm{mm}^{3}\right)$ as defined by CTCAE v3.0 [7].

The demographic data and the platelet count change through the treatment course in the 3 studied groups revealed significant positive correlation between baseline body weight and platelet count change in the 2nd week, 4th week and end of treatment in the SOF/RBV therapy only $(r=0.27,0.46,0.288 ; p=0.04,0.001,0.03$, respectively).

The triple therapy group demonstrated statistically significant negative correlation between FIB-4 score and the platelet count in the 2nd week $(p<0.047)$ but not at the 4th week or end of treatment, while this correlation was significant for group 2 at the 2nd and 4th weeks and for group 3 at the 4th week only $(p<0.001)$. There is no correlation between duration of illness and platelet count in the three groups (Table 5).

Table 2 Comparison of parameteric parameters of the three antiviral groups $(p>0.0)$

\begin{tabular}{|c|c|c|c|c|}
\hline & \multicolumn{3}{|l|}{ Group } & \multirow[b]{2}{*}{$p$ value } \\
\hline & SIM/SOF & SOF/RBV & Triple & \\
\hline Age (years) & $55.05 \pm 8.00$ & $53.93 \pm 9.27$ & $53.55 \pm 7.56$ & 0.764 \\
\hline Weight (Kg) & $81.73 \pm 15.29$ & $81.35 \pm 12.41$ & $80.05 \pm 13.55$ & 0.626 \\
\hline Height (m) & $1.64 \pm .08$ & $1.66 \pm .10$ & $1.68 \pm .09$ & 0.092 \\
\hline $\mathrm{BMI}\left(\mathrm{Kg} / \mathrm{m}^{2}\right)$ & $30.36 \pm 6.09$ & $29.81 \pm 4.39$ & $28.40 \pm 4.48$ & 0.099 \\
\hline HCV positivity (years) & $2.26 \pm 2.81$ & $6.67 \pm 6.30 *$ & $4.18 \pm 5.85$ & $<0.001$ \\
\hline Fib 4 calculation & $5.10 \pm 2.78$ & $7.77 \pm 3.79 *$ & $3.74 \pm 1.43 * \#$ & $<0.001$ \\
\hline Baseline platelets $\left({ }^{*} 1000 / \mathrm{mm}^{3}\right)$ & $111.84 \pm 40.35$ & $77.18 \pm 18.01 *$ & $136.89 \pm 31.70 * \#$ & $<0.001$ \\
\hline Baseline TLC $\left({ }^{*} 1000 / \mathrm{mm}^{3}\right)$ & $4.89 \pm 1.35$ & $4.89 \pm 1.52$ & $5.97 \pm 1.99 * \#$ & 0.002 \\
\hline Baseline ANC $\left({ }^{*} 1000 / \mathrm{mm}^{3}\right)$ & $2.64 \pm .95$ & $2.59 \pm 1.01$ & $3.11 \pm 1.27 * \#$ & 0.028 \\
\hline Baseline $\mathrm{Hb}(\mathrm{g} / \mathrm{dl})$ & $12.63 \pm 1.38$ & $12.97 \pm 1.69$ & $13.86 \pm 1.58 * \#$ & $<0.001$ \\
\hline Baseline Alt (IU/I) & $57.35 \pm 39.05$ & $64.52 \pm 37.95$ & $75.04 \pm 58.82$ & 0.198 \\
\hline Baseline Ast (IU/I) & $65.58 \pm 36.44$ & $\begin{array}{l}78.14 \pm \\
42.81\end{array}$ & $72.91 \pm 51.74$ & 0.106 \\
\hline Baseline Bil T (mg/dl) & $.99 \pm .39$ & $1.18 \pm .57$ & $.99 \pm .69 \#$ & 0.024 \\
\hline Baseline Alb (g/dl) & $3.50 \pm .46$ & $3.44 \pm .46$ & $3.95 \pm .44{ }^{*} \#$ & $<0.001$ \\
\hline Baseline PC (\%) & $79.38 \pm 12.46$ & $75.20 \pm 13.93$ & $81.98 \pm 15.38 \#$ & 0.015 \\
\hline Baseline Creat (mg/dl) & $.74 \pm .20$ & $.80 \pm .19$ & $.83 \pm .23$ & 0.088 \\
\hline Creat clearance (ml/min) & $120.94 \pm 33.11$ & $116.76 \pm 31.33$ & $113.68 \pm 30.77$ & 0.663 \\
\hline Baseline HCV RNA by PCR (IU/ml) & $949,173.30 \pm 1195,220.29$ & $1,051,988.49 \pm 1,824,411.25$ & $2,473,014.05 \pm 6631,407.20$ & 0.256 \\
\hline TSH $(\mu \mathrm{IU} / \mathrm{ml})$ & $1.92 \pm 1.46$ & $1.97 \pm 2.05$ & $1.67 \pm 1.20$ & 0.518 \\
\hline Alpha fetoprotien (IU/I) & $15.66 \pm 22.75$ & $28.92 \pm 29.11 *$ & $21.00 \pm 30.15$ & 0.001 \\
\hline
\end{tabular}


Table 3 Platelet decrement during treatment

\begin{tabular}{|c|c|c|c|c|c|c|c|c|}
\hline \multirow[t]{2}{*}{$\begin{array}{l}\text { Platelet count } \\
\text { decrements }\end{array}$} & \multicolumn{2}{|c|}{ All studied patients } & \multicolumn{2}{|c|}{$\begin{array}{l}\text { Group } 1 \\
\text { Triple } \\
\end{array}$} & \multicolumn{2}{|c|}{$\begin{array}{l}\text { Group } 2 \\
\text { SOF/RBV }\end{array}$} & \multicolumn{2}{|c|}{$\begin{array}{l}\text { Group } 3 \\
\text { SIM/SOF }\end{array}$} \\
\hline & No. & $\%$ & No. & $\%$ & No. & $\%$ & No. & $\%$ \\
\hline \multicolumn{9}{|l|}{2 Weeks } \\
\hline Decrease & 128 & $76.2 \%$ & 50 & $89.3 \%$ & 34 & $61.8 \%$ & 44 & $77.2 \%$ \\
\hline No decrease & 40 & $23.8 \%$ & 6 & $10.7 \%$ & 21 & $38.2 \%$ & 13 & $22.8 \%$ \\
\hline \multicolumn{9}{|l|}{4 Weeks } \\
\hline Decrease & 120 & $71.4 \%$ & 46 & $82.1 \%$ & 26 & $47.3 \%$ & 48 & $84.2 \%$ \\
\hline No decrease & 48 & $28.6 \%$ & 10 & $17.9 \%$ & 29 & $52.7 \%$ & 9 & $15.8 \%$ \\
\hline \multicolumn{9}{|l|}{ End of treatment } \\
\hline Decrease & 91 & $54.8 \%$ & 41 & $73.2 \%$ & 16 & $29.1 \%$ & 34 & $61.8 \%$ \\
\hline No decrease & 75 & $45.2 \%$ & 15 & $26.8 \%$ & 39 & $70.9 \%$ & 21 & $38.2 \%$ \\
\hline
\end{tabular}

Least decrement\% was observed in SOF/RBV

There was no statistically significant correlation between the child score calculation, ultrasonographic findings, the degree of fibrosis and necroinflammatory activity with the platelet count decrement through the course of the triple antiviral therapy, SOF/RBV and SIM/SOF antiviral therapy groups (data not shown).

The drop in PCR was significantly correlated with the improvement of platelet count $(p<0.05)$ in SOF/ RBV arm in the second and fourth weeks as illustrated in Fig. 2.

During treatment, five patients $(8.9 \%)$ in the INF treatment group and one patient $(1.8 \%)$ in the SOF/RBV group required dose modification. None of the patients in the SIM/SOF group required dose modification. The reported response rate is $100 \%$ in the triple therapy group, $98.2 \%$ in the SOF/RBV group and $96.4 \%$ in the SIM/SOF group.

Table 4 Mean platelet count in diffrent weeks of treatment

\begin{tabular}{|c|c|c|c|c|c|}
\hline $\begin{array}{l}\text { Platelet count } \\
\left(\times 10^{3} \text { cell//mm }\right)\end{array}$ & $\begin{array}{l}\text { All patients } \\
\text { mean } \pm \text { SD, } \\
\text { mean PLT, } \% \\
\text { drop to baseline }\end{array}$ & $\begin{array}{l}\text { Group } 1 \\
\text { Triple } \\
\text { (n 56), mean PLT, } \\
\text { \% drop to baseline }\end{array}$ & $\begin{array}{l}\text { Group } 2 \\
\text { SOF/RBV } \\
\text { (n 55) mean PLT, } \\
\% \text { drop to baseline }\end{array}$ & $\begin{array}{l}\text { Group } 3 \\
\text { SIM/SOF } \\
\text { ( } n \text { 57) } \\
\text { mean PLT, \% drop } \\
\text { to baseline }\end{array}$ & $\begin{array}{l}p \text { value } \\
\text { (among three } \\
\text { groups) }\end{array}$ \\
\hline Baseline PLT & $108.85 \pm 39.74$ & $136.89 \pm 31.70$ & $77.18 \pm 18.01$ & $111.84 \pm 40.35$ & $<0.001$ \\
\hline Week 1 & $\begin{array}{l}89.72 \pm 27.93 \\
18 \%\end{array}$ & $\begin{array}{l}86.89 \pm 23.62 \\
37 \%\end{array}$ & $\begin{array}{l}75.89 \pm 14.09 \\
3 \%\end{array}$ & $\begin{array}{l}105.84 \pm 33.56 \\
6 \%\end{array}$ & $<0.001$ \\
\hline Week 2 & $\begin{array}{l}90.87 \pm 33.90 \\
17 \%\end{array}$ & $\begin{array}{l}99.50 \pm 36.89 \\
28 \%\end{array}$ & $\begin{array}{l}72.58 \pm 12.30 \\
7 \%\end{array}$ & $\begin{array}{l}100.04 \pm 38.18 \\
10 \%\end{array}$ & $<0.001$ \\
\hline Week 3 & $\begin{array}{l}87.65 \pm 25.17 \\
20 \%\end{array}$ & $\begin{array}{l}96.05 \pm 28.4 \\
30 \%\end{array}$ & $\begin{array}{l}76.07 \pm 13.23 \\
2 \%\end{array}$ & $\begin{array}{l}90.58 \pm 26.68 \\
19 \%\end{array}$ & $<0.001$ \\
\hline Week 4 & $\begin{array}{l}88.46 \pm 32.08 \\
19 \%\end{array}$ & $\begin{array}{l}101.71 \pm 44.1 \\
26 \%\end{array}$ & $\begin{array}{l}77.55 \pm 14.26 \\
0 \%\end{array}$ & $\begin{array}{l}85.98 \pm 25.69 \\
24 \%\end{array}$ & $<0.001$ \\
\hline Week 8 & $\begin{array}{l}94.98 \pm 37.93 \\
13 \%\end{array}$ & $\begin{array}{l}97.05 \pm 39.27 \\
29 \%\end{array}$ & $87.73 \pm 30.95$ & $\begin{array}{l}99.93 \pm 42.08 \\
11 \%\end{array}$ & 0.312 \\
\hline Week 12 & $\begin{array}{l}99.46 \pm 41.84 \\
9 \%\end{array}$ & $\begin{array}{l}102.86 \pm 46.37 \\
25 \%\end{array}$ & $90.16 \pm 30.62$ & $\begin{array}{l}105.31 \pm 45.67 \\
6 \%\end{array}$ & 0.17 \\
\hline
\end{tabular}

\section{Discussion}

Thrombocytopenia is frequent among patients with chronic hepatitis $\mathrm{C}$ virus and cirrhosis and is further aggravated by the IFN-based antiviral therapy. The development of DAA has significantly improved tolerability of treatment and cure rates. In Egypt, with the approval of sofosbuvir (SOF), different SOFbased therapies became the standard of care. We performed a retrospective study to compare the incidence of thrombocytopenia during treatment with three of the DAA regimens available for HCV treatment in Egypt. We found more noticeable lowering of mean platelet count in the 2nd week and 4th week of treatment followed by the rise of platelet count again in all the studied groups. Patients on triple therapy (group 1) showed earlier drop of platelet count (1st week) and did not return to baseline till the end of treatment. 


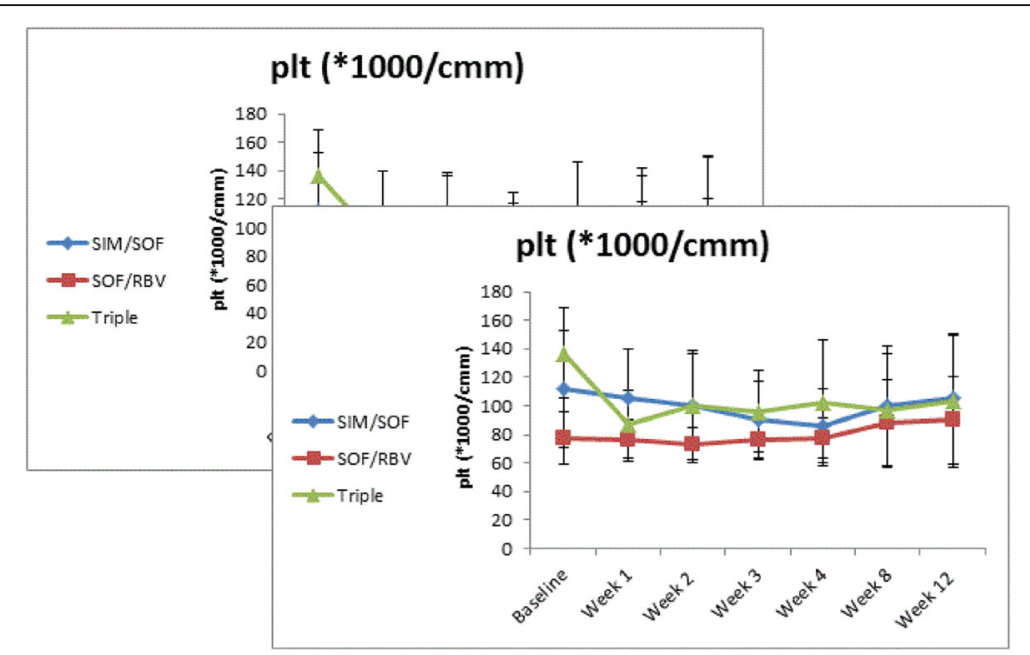

Fig. 1 Changes in mean platelet count during therapy

On the evaluation of the overall number of patients with platelet count decrement, we found that most of the enrolled patients $(76.2 \%, 71.4 \%)$ demonstrated platelet count decrement in the 2nd and 4th weeks with mean platelet counts of $87.65 \pm 25.17 \times 10^{3} / \mu \mathrm{l}$ and $88.46 \pm 32.08 \times 10^{3} / \mu$ l, respectively, which improved towards the end of treatment: $54.8 \%$ of patients demonstrated platelet decrement with a mean platelet count of $99.46 \pm 41.84$.
In comparing the 3 therapeutic groups, the triple therapy group showed the highest proportion of patients with platelet decrement. While the SOF/RBV group showed the lowest mean platelet count at the 2nd week, 4th week and end of treatment. This could be explained by the lower pre-treatment platelet count in the SOF/ RBV group in comparison with the other groups and the presence of more unfavourable features as higher proportion of patients with splenomegaly and those who

Table 5 Correlation between duration of illness and PLT count and between FIB-4 and PLT count in the three treatment groups

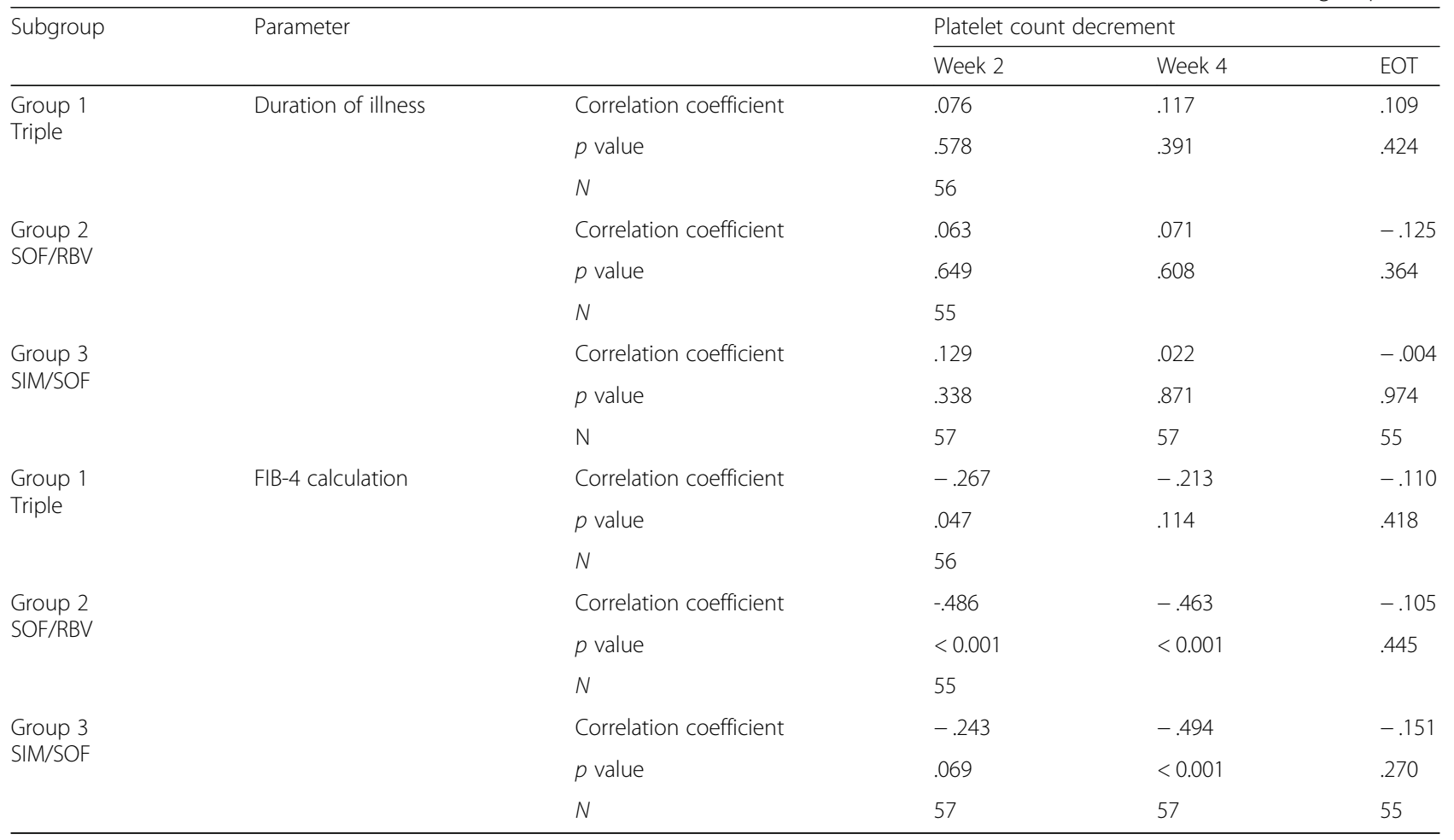




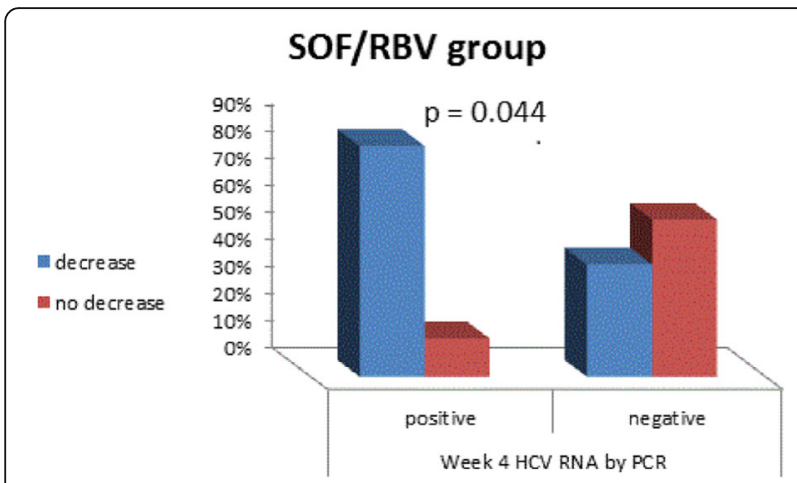

Fig. 2 Comparison between change in the platelet count in week 4 and HCV RNA by PCR

received previous treatment. It is worth mentioning that the percentage of patients affected by this significant thrombocytopenia was lower in this group compared with the other two groups in all stages of assessment.

In a large study involving 125 patients with chronic hepatitis $\mathrm{C}$ and baseline thrombocytopenia who received antiviral therapy with peg-IFN-a and ribavirin, it was found that platelet count was less than 100,000 before onset of treatment, and rapid early drop of platelet count on treatment are predictors of high risk of developing on-treatment severe thrombocytopenia $[8,9]$.

But both studies were done on peg-INF/RBV, and this arm in our study had baseline platelet count of more than 100,000/l unlike the other two arms, but still the rule of $100,000 / \mu$ l could be applicable.

We compared response to therapy in the 3 subgroups of antiviral therapy and noticed that rapid virological response was in the triple antiviral therapy group, but this was not statistically significant to the other arms as well as associated with more cases that required dose modification due to thrombocytopenia in this arm. Five of six patients who required dose modification were noticed in the triple antiviral therapy group and no dose modification was needed for the SIM/SOF group.

All the three arms were associated with SVR above 95\% at week 12 with no statistical difference in between. There are data that support better SVR on SOF/REB [7, 10]. Others proved less efficacy for SOF/REB vs other different combinations of DAAs or even IFN-based therapies [11-13].

On studying the demographic data of the patients, we found that the lower the baseline weight of the patients, the more the development of thrombocytopenia during SOF/RBV therapy. However, BMI did not show significant correlation in our study. This is not in agreement with Lin et al., who found that low body mass index $(p=0.022)$ was significantly correlated with the development of thrombocytopenia but they used the INF/Rib combination [8].
In our study, we found that the lower the baseline albumin of the patients, the more the development of thrombocytopenia during triple therapy. This is in agreement with Lin et al., who also found that low albumin was significantly correlated with the development of thrombocytopenia [8]. This was not applicable for the other two arms. The interpretation may be because this arm has more thrombocytopenia with lower hepatic synthetic functions from the start. But this confirms that poorer baseline liver function is a predictor of thrombocytopenia during antiviral therapy.

It was found that cirrhosis was associated with thrombocytopenia during antiviral therapy which did not show significant correlation in our study [9].

We found that the lower baseline absolute neutrophil count was not associated with significant decrement in platelet count. On the contrary, Nachnani et al., reported that lower white blood cell count was associated with thrombocytopenia during antiviral therapy [14]. The reason could be that the interferon arm patients were chosen with good $\mathrm{CBC}$ from the start and that the other two drug combinations have less side effects on $\mathrm{CBC}$. Larger studies on patients with chronic hepatitis $C$ and thrombocytopenia should be conducted for further studying of the suggested predicting factors and followup for platelet counts after end of antiviral therapy is very important with the DAAs. We also found that by the end of treatment (EOT), all patients had normalized platelet (PLT) count regardless of the initial count.

\section{Conclusion}

The recent change in direct-acting antiviral therapy (DAA) without IFN, as the frontline therapy for HCV, permits to avoid the dilemmas associated with initiating or maintaining IFN-based antiviral therapy. DAAs, with high SVR and few haematological adverse effects, have been shown to improve thrombocytopenia associated with HCV infection as well as advanced hepatic disease. The second and fourth weeks of antiviral therapy show most decrement of platelet count.

Antiviral therapy in general does not induce sever thrombocytopenia.

Triple therapy (INF/SOF/RBV ) induced more thrombocytopenia rather than SOF/RBV.

\section{Acknowledgements}

We are thankful to all the patients who participated in this work.

\section{Authors' contributions}

All authors participated in the manuscript revision. SGh collected the references and prepared the data from patients' files. NH wrote the manuscript and revised the statistics. DD and MT put the research idea. AH, $H D$, and $A F$ revised the data. MR revised the paper and participated in response to reviewers' comments. The authors read and approved the final manuscript. 
Funding

None to declare

\section{Availability of data and materials \\ All data are available.}

Ethics approval and consent to participate

The research has been approved by REC of Cairo University ID 3361.

\section{Consent for publication}

Verbal consent from all participants were obtained.

\section{Competing interests}

The authors declare that they have no competing interests.

\section{Author details}

${ }^{1}$ Internal Medicine Department, Faculty of Medicine, Cairo University, Cairo, Egypt. ${ }^{2}$ Armed Forces Faculty of Medicine (AFCM), Cairo, Egypt. ${ }^{3}$ National Hepatology and Tropical Institute, Cairo, Egypt. ${ }^{4}$ Internal Medicine Department, Faculty of Medicine, Beni Suef University, Beni Suef, Egypt.

Received: 1 May 2020 Accepted: 20 August 2020

Published online: 01 September 2020

\section{References}

1. Abd Elrazek AE, Bilasy SE, Elbanna AE, Elsherif AE (2014) Prior to the oral therapy, what do we know about HCV-4 in Egypt: a randomized survey of prevalence and risks using data mining computed analysis. Medicine (Baltimore) 93(28):e204

2. Fried $M$, Shiffman $M$, Reddy $K$ et al (2002) Peginterferon alfa-2a plus ribavirin for chronic hepatitis C virus infection. N Engl J Med 347:975-982

3. McHutchison J, Manns M, Patel K et al (2002) Adherence to combination therapy enhances sustained response in genotype-1-infected patients with chronic hepatitis C. Gastroenterology 123:1061-1069

4. Shiffman M, Ghany M, Morgan T et al (2007) Impact of reducing peginterferon alfa-2a and ribavirin dose during retreatment in patients with chronic hepatitis C. Gastroenterology 132:103-112

5. Martínez S, Crespo G, Navasa M et al (2011) Noninvasive assessment of liver fibrosis. Hepatology 53:325-335

6. Cholongitas E, Papatheodoridis G, Vangeli M et al (2005) Systematic review: The model for end-stage liver disease--should it replace Child-Pugh's classification for assessing prognosis in cirrhosis? Aliment Pharmacol Ther 22:1079-1089

7. Seo K, Kim SK, Kim SR et al (2017) Comparison of Sofosbuvir Plus Ribavirin Treatment with Pegylated Interferon Plus Ribavirin Treatment for Chronic Hepatitis C Genotype 2. Dig Dis 35:541-547

8. Lin $\mathrm{K}$, Ping $\mathrm{H}-\mathrm{H}$, Hsien-Chung $\mathrm{Y}$ et al (2012) Factors linked to severe thrombocytopenia during antiviral therapy in patients with chronic hepatitis C and pretreatment low platelet counts. BMC Gastroenterol 12:7-14

9. Roomer R, Hansen B, Janssen $\mathrm{H}$ et al (2010) Thrombocytopenia and the risk of bleeding during treatment with peginterferon alfa and ribavirin for chronic hepatitis C. J Hepatol 53:455-459

10. Nagaty A, Abd El-Wahab EW (2017) Real-life results of sofosbuvir based therapy in chronic hepatitis $C$-naïve and -experienced patients in Egypt. PLoS One 12(10):e0184654

11. Aisha Elsharkawy, Maissa El-Raziky, Wafaa El-Akel, Kadry El-Saeed, Rasha Eletreby, Mohamed Hassany, Manal Hamdy El-Sayed, Khaled Kabil, Sohier A Ismail, Magdy El-Serafy, Ashraf Omar Abdelaziz, Mohamed Kamal Shaker, Ayman Yosry, Wahid Doss, Yehia El-Shazly, Gamal Esmat, Imam Waked. Planning and Prioritizing Direct-Acting Antivirals Treatment for HCV Patients in Countries With Limited Resources: Lessons From the Egyptian Experience. J Hepatol. 2018;68(4):691-698. doi: https://doi.org/10.1016/j.jhep.2017.11.034. Epub 2017 Dec 6.

12. Elsharkawy A, Fouad R, El Akel W, El Raziky M, Hassany M, Shiha G, Said M, Motawea I, El Demerdash T, Seif S, et al. Sofosbuvir-based treatment regimens: real life results of 14409 chronic HCV genotype 4 patients in Egypt. Aliment Pharmacol Ther. 2017;45:681-687. [PubMed] [Google Scholar]

13. El Kassas M, Alboraie M, Omran D, Salaheldin M, Wifi MN, ElBadry M, El Tahan A, Ezzat S, Moaz E, Farid AM, et al. An account of the real-life hepatitis $C$ management in a single specialized viral hepatitis treatment centre in Egypt: results of treating 7042 patients with 7 different direct acting antiviral regimens. Expert Rev Gastroenterol Hepatol. 2018 Epub ahead of print. [PubMed] [Google Scholar]

14. Nachnani J, Rao G, Bulchandani D et al (2010) Predictors of hematological abnormalities in patients with chronic hepatitis $C$ treated with interferon and ribavirin. Ann Hematol 89:121-125

\section{Publisher's Note}

Springer Nature remains neutral with regard to jurisdictional claims in published maps and institutional affiliations.

\section{Submit your manuscript to a SpringerOpen ${ }^{\circ}$ journal and benefit from:}

- Convenient online submission

- Rigorous peer review

- Open access: articles freely available online

- High visibility within the field

- Retaining the copyright to your article

Submit your next manuscript at $\boldsymbol{\nabla}$ springeropen.com 